\title{
AN OCCURRENCE OF METASOMATIC ALUMINOSILICATES RELATED TO HIGH ALUMINA HYDROTHERMAL ALTERATION WITHIN THE SOUTH MOUNTAIN BATHOLITH, NOVA SCOTIA
}

\author{
Michael C. Corey \\ Nova Scotia Department of Mines and Energy \\ Halifax, Nova Scotia B3J $2 X I$ \\ Date Received October 15, 1987 \\ Date Accepted March 28, 1988
}

\begin{abstract}
A zone of high alumina hydrothermal alteration (HAHA) is documented within granitoid rocks of the Big Indian Polyphase Intrusive suite (BIPI su1te), wh1ch forms part of the Late Devonian-Early Carboniferous South Mountain Batholith (SMB). The alteration, wh1ch 1s confined to a NE-trending shear zone, 1s characterized by the quartz-deficient minera1 assemblage andalus1te-s1lilman1te-spinel-muscovite-cordierite-apatite-pyrite. The HAHA zone represents the flrst reported occurrence of this alteration type within the South Mountain Batholith.

Field observations indicate that the HAHA zone is only one of a series of successive and superimposed metasomatichydrothermal events which, together with $\mathrm{W}-\mathrm{Cu}-\mathrm{Mo}_{0}+\mathrm{U}-\mathrm{Cu}$ mineralization, exh1bit a transition in style from early pervasive to late fracture-controlled. Th1s change in style within the BIPI suite is considered to reflect a progressive increase in fluld pressure.

Petrography and mineral chemistry suggest that the HAHA zone formed in response to the interaction of the leucomonzogranite host with a $\mathrm{Na}(+\mathrm{A} 1)-\mathrm{rlch}$, silica-undersaturated fluid. Although speculative, alumina may have been a moblle element transported as an alkali-complex via the fluid. High temperature mineral assemblages (andalusites1llimanite: andalusite-spine1) indicate that the initial temperature of the aqueous fluid phase was $\geq 620^{\circ} \mathrm{C}$ for $2 \mathrm{~kb}$ pressure. It 1s proposed that the fluld phase represents a residual magmatic-fluid which was accessed by deep-seated
\end{abstract} fracturing.

On documente une zone d'altération hydrothermale hautement alumineuse (AHHA) à l'intèrieur des granitö̈des de la suite Intrusive Polyphasee de B1g Indian (suite IPBI) qui fait partie du Batholite de South Mountain (BSM) d'âge tardidévonien à éocarbonifère. Confinèe à une zone de cisaillement à tendance NE, l'alteration est caracterisêe par un assemblage de mineraux, deficient en quartz, a andalousite-sillimanite-spinelle-muscovite-cordierite-apatitepyrite. La zone AHHA représente la premiére mention de ce type d'alteration à l'intérieur du BSM.

D'après les observations sur le terrain, cette zone AHHA n'est qu'un d'une série d'evenements métasomatiques et hydrothermaux successifs et superposés qui, ainsi qu'une mineralisation en $W-C u-M o+U-C u$, exhibent un style d'abord pénetrant et enfin filonien. On considére que ce changement de style a l'Intérieur de la suite IPBI représente un accroissement progressif de la pression des fluides.

La pétrographle et le chimisme des minéraux tendent à montrer que la zone AHHA s'est établie en réponse à 1 'interaction de l'encalssant leucomonzogranitique avec un fluide sous-sature en silice et riche en NatAl. Bien que cela reste spéculatif. l'alumine pourrait avoir été un élément mobile transporté par le fluide à l'état de complexe alcalin. D'aprés les assemblages de mineraux à haute temperature (andalousite-sililimanite; andalousite-spinelle). la temperature 1nitiale de la phase aqueuse fluide était $>620 \mathrm{C}$ pour une pression de $2 \mathrm{~kb}$. On propose que la phase fluide repressente un fluide magmatique ressiduel extra1t par une fracturation en profondeur.

[Traduit par le journal]

\section{INTRODUCTION}

The term 'high alumina alteration' was first used by Schmidt (1985) to describe the alteration assemblage: andalusite, diaspore, pyrophyllite, and topaz associated with gold deposits of the Carolina Slate Belt. He devised the term to distinguish the kaolinite and alunite types of hydrothermal alteration (i.e., advanced argillic) commonly seen in the upper part of some porphyry copper deposits from higher temperature equivalents containing andalusite.

High alumina hydrothermal alteration (HAHA) is associated with a variety of mineral deposit types. These deposit types include (i) porphyry type $\mathrm{Cu}-$ Mot Au deposits (Gustafson and Hunt, 1975; Brimha11, 1977; Steefel and Atkinson, 1984; and Schmidt, 1985); (1i) massive sulphide deposits (e.g., Boliden, Sweden, Nilsson, 1968; Chizevil, France, Lemiere et al., 1986); and (iii) epithermal $\mathrm{Au}+\mathrm{Ag}$ deposits (e.g., Chetwynd, Nfld., McKenzie, 1986; Toodoggone, B.C., Panteleyev, 1986;
Carolina Slate Be1t, USA, Schmidt, 1985). Although the mineral assemblage resulting from HAHA can vary, the presence of andalusite appears to be characteristic. The HAHA zone described in this paper is the first reported from the South Mountain Batholith (SMB) and is characterized by the hyperaluminous mineral assemblage, andalusite + sillimanite + cordierite + muscovite \pm spine1, with accessory minerals including pyrite $(\leq 5 \%)$. fluorite, tourmaline, apatite, chalcopyrite, covellite, and rarely sphalerite.

The purpose of this paper is to describe and discuss various aspects regarding the petrography and mineral chemistry of the HAHA zone and host granitoid rocks. The nature of the hydrothermal system prevailing during the high alumina alteration will also be addressed.

\section{GENERAL GEOLOGY}

The HAHA zone is found within rocks of the Big Indian Polyphase Intrusive suite (BIPI suite.

MARITIME SEDIMENTS AND ATLANTIC GEOLOGY

$24.83-95$ (1988) 
Fig. 1). The BIPI suite is situated near the eastern margin of the SMB and is comprised of two large $\left(18-20 \mathrm{~km}^{2}\right)$ granitold bodies emplaced into a biotite granodiorite unit of the SMB (Corey, 1986; Ham and Horne, 1986). The SMB is a post-tectonic, peraluminous suite of granitold rocks, which occupies a large portion $\left(10,000 \mathrm{~km}^{2}\right)$ of southwestern Nova Scotia. Details regarding its petrology, and geochemistry are well documented (McKenzie and Clarke, 1975; Clarke and Muecke. 1985; Clarke et al., 1985).

\section{GEOLOGY OF THE BIPI SUITE}

The BIPI suite has been divided into four mineralogically similar, but texturally variable units which include biotite \pm muscovite and cordierite monzogranite, leucomonzogranite ( $\leq 6 \%$ biotite). leucogranite ( $\leq 2 \%$ blotite) and minor syenogranite (nomenclature after Streckeisen. 1976). The textural varlations include: (1) mediumto-coarse grained to megacrystic; (2) porphyritic; (3) fine-to-medium grained; and (4) very finegrained equigranular (herein termed microgranite). These units display sharp irregular contacts and contain abundant biotite granodiorite xenoliths (roof pendants?) which in turn possess numerous metasedimentary xenoliths of variable size $\left(\leq 10 \mathrm{~m}^{2}\right)$ and shape. No metasedimentary xenoliths have been observed within rocks of the BIPI suite.

The unusual shape of the BIPI suite, together with zones of intense shearing both at contacts and internally suggests that its emplacement was controlled by pre-existing regional fault (basement?) structures. The occurrence of shear fabrics both within and adjacent to the BIPI suite may represent rejuvenation of some of these structures.

A well exposed serles of NW trending, steeply dipping faults (and mylonite zones) which separate the BIPI suite into two halves suggests that at one time the BIPI suite constituted a single pluton.

\section{PETROGRAPHY OF THE BIPI SUITE}

The above units of the BIPI suite are characterized by containing variable amounts of the hyperaluminous mineral assemblage muscovite, garnet, cordierite, andalusite, and sillimanite.

Muscovite displays a varlety of textures (al1 which imply subsolidus growth) and habits, ranging from large euhedral laths which have overgrown other minerals to fine-grained, anhedral crystals and crystal masses (sericite) which occur both surrounding and replacing other minerals (e.g., Kfeldspar, plagioclase, biotite, garnet, aluminosilicate).

Aluminosilicates most commonly are $\operatorname{smal1}(\leq 1 \mathrm{~mm})$ subhedral to anhedral andalusite crystal remnants hosted by and replaced (mantled) by muscovite (sericite) and also cordierite (pinite). Small ( $\leq 1$ $\mathrm{mm}$ ) euhedral crystals of andalusite were also observed within a sample of microgranite. Sillimanite (except in the HAHA zone) is restricted to fibrolitic masses within microfractures and surrounding garnets.

Cordierite, invariably pinitized, occurs both as anhedral crystals replacing andalusite and coexisting with it as small ( $\leq 1 \mathrm{~mm}$ ) subhedral crystals within muscovite.

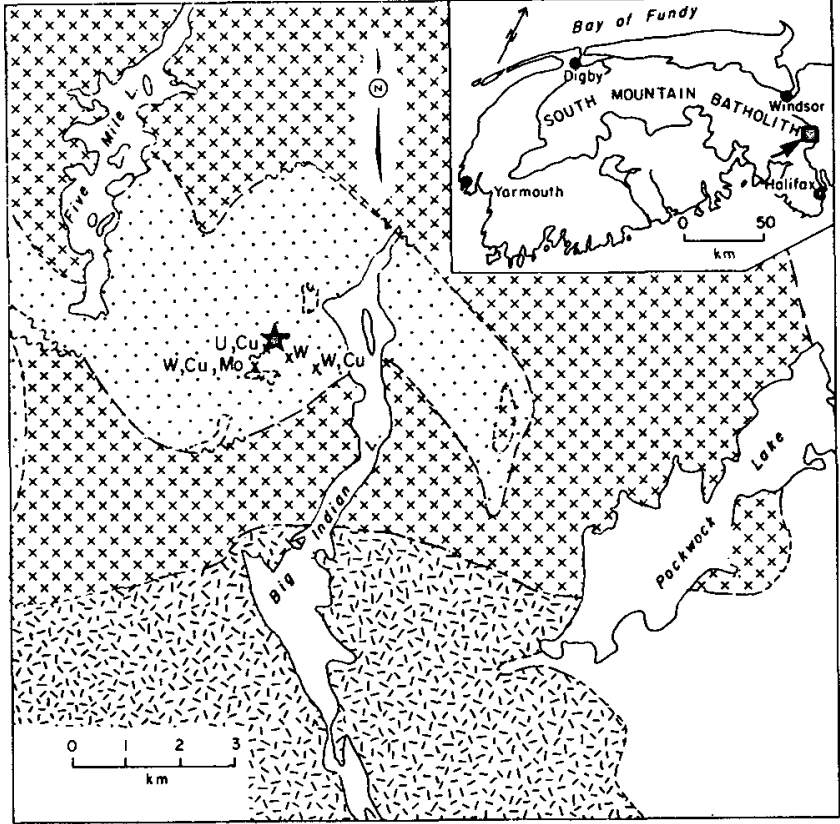

\section{LEGEND}

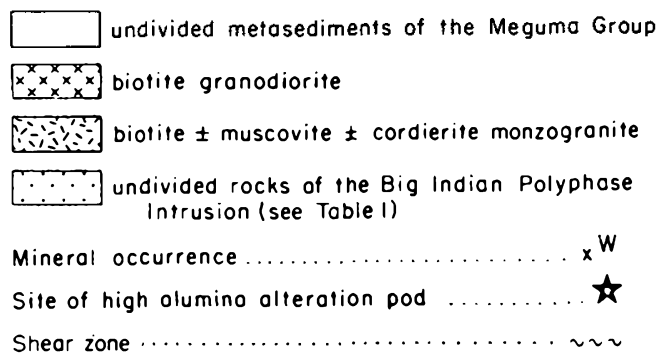

F1g. 1. General geology and location map for study area, showing HAHA zone and mineral occurrences.

Garnet commonly occurs as $\leq 1 \mathrm{~cm}$ anhedral polycrystalline (with quartz, sphene, and fibrolite) aggregates disseminated throughout the rocks and in narrow, $\mathrm{K}$-feldspar-rich dykes which cross-cut the microgranite. Garnet is spessartinerich and displays a strong antithetic relationship with biotite. A metasomatic origin has been suggested based on textural and chemical evidence (Kontak and Corey, in press).

\section{ALTERATION AND MINERALIZATION}

Figure 2 summarizes the various types and styles of alteration observed within the units of the BIPI suite. It is apparent from this figure that although metasomatic effects are present in all units, they are most intense within and proximal to the microgranite. This strongly suggests a genetic link between the fluids associated with the microgranite and the metasomatic-hydrothermal process.

Several different types of mineralization occur within the BIPI suite (Figs. 1, 2). Perhaps the most significant economicalis are the $\mathrm{N}-\mathrm{S}$ trending, steeply dipping, enechelon quartz veins which contain coarse disseminations of wolframite (altering to scheelite), with minor chalcopyrite and molybdenite. The veins vary in width from 1 to 
$10 \mathrm{~cm}$ and are confined to the microgranite. The irregular shape and vuggy nature of the veins suggest that they filled dilatant zones within the microgranite.

Also located within the microgranite are chlorite, albite and tourmaline-bearing greisen veins and sma11 ( $\left.\leq 10 \mathrm{~cm}^{2}\right)$ pyrite- and chalcopyritebearing greisen pods. The greisen veins have the same orientation as the quartz veins and no crosscutting relationships were observed.

Low-grade uranium-phosphate (torbernite \pm autunite) and minor chalcopyrite mineralization associated with intense hematization is restricted to a prominent NE-trending shear zone which transects all phases of the BIPI suite.

The occurrence of tourmaline and fluorite are rare within the BIPI suite and appears to be associated with the later stages of hydrothermal activity. Evidence for this is the occurrence of several small ( $\left.\leq 20 \mathrm{~cm}^{2}\right)$ pods of massive black tourmaline within a NE-trending shear zone.

Field observations (Fig. 2) suggest that repeated and superimposed periods of alteration and mineralization occurred within the BIPI suite and that early pervasive styles of alteration (pervasive garnet metasomatism) and mineralization (greisen pods) were overprinted by later, fracturecontrolled styles (HAHA zone, W-bearing quartz velns).

Pollard and Taylor (1986) proposed that such a transformation is due to progressive fracturing in response to increasing fluid pressure accompanied by tapping of a magmatic fluid reservoir at different evolutionary stages. The presence of extensive microfracturing within the microgranite and prominent later shearing which cross-cut all BIPI suite units suggests that a process of progressive fracturing occurred.

\section{HIGH ALUMINA HYDROTHERMAL ALTERATION ZONE}

The HAHA zone forms a lenticular body approximately $10 \mathrm{~m}$ long $\times 3 \mathrm{~m}$ wide within the same shear zone that hosts the U-Cu mineralization. The occurrence of an intensly hematitized and autunitebearing portion of the HAHA zone indicates that it was a product of an earlier metasomatic event which was overprinted by U-bearing fluids. In outcrop the HAHA zone is characterized by the presence of abundant $(\leq 20 \%)$ euhedral andalusite in addition to sillimanite, spinel, muscovite, disseminated pyrite $(\leq 5 \%)$, minor chalcopyrite, covellite, sphalerite, and light green apatite. Garnet and quartz are absent from the zone of HAHA, although both are present in rocks immediately surrounding 1 t.

Mineralogy, Petrography and

Mineral Chemistry of HAHA Zone

Table 1 provides a description of the principal mineral phases within the HAHA zone and summarizes the textures and phase relationships discussed below. Mineral chemistry data was collected using a Jeo1 733 electron microprobe located at Dalhousie University, Nova Scotia. The microprobe utilizes four wavelength spectrometers with a Tracor Northern $145 \mathrm{ev}$ Energy Dispersive System using the following operating parameters: accelerating

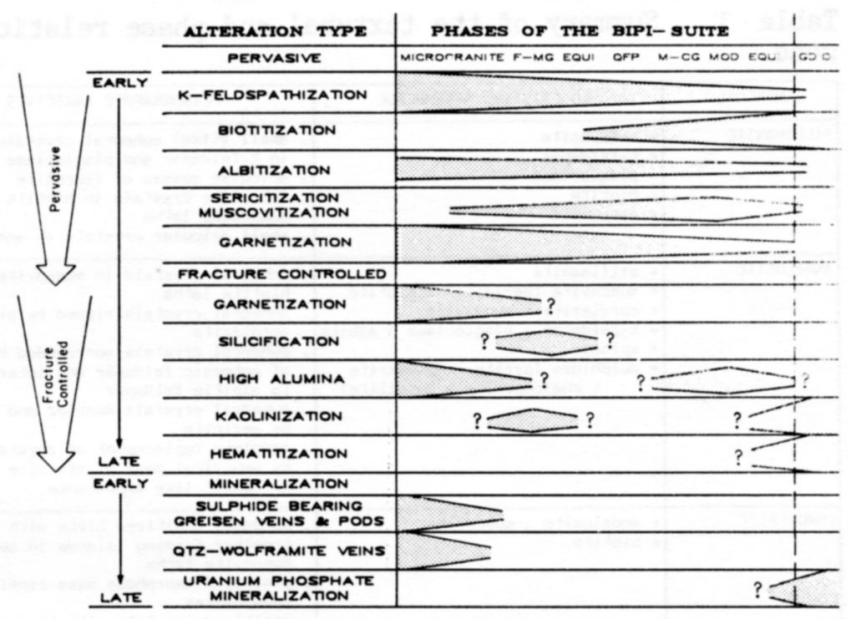

F1g. 2. Chronological sequence of alteration and mineral1zation types within the BIPI sulte. Alteration exhibits transition in style from early pervasive to later fracture controlled. The unit in which the alteration is observed 1s also displayed; the units are 11sted beginning with the latest intrusive(?) unit (microgranite). The wider the bar the more intense the particular type of alteration.

voltage, $15 \mathrm{kV}$; probe current, $5 \mathrm{nA}$; counting time, 40 sec/element. A Tracor Northern ZAF MATRIX correction program was also used.

\section{Andalusite}

In hand sample andalusite is readily observed as long ( $\leq 2.5 \mathrm{~cm})$, pinkish-red crystals commonly surrounded by a halo $(\leq 3 \mathrm{~mm})$ of $11 \mathrm{ght}$ orange feldspar. In thin section the andalusite occurs as euhedral to subhedral crystals and crystal aggregates of prismatic to stubby habit (P1ate la) overgrowing and replacing mineral phases, particularly plagloclase feldspar. Inclusions of albite, biotite, muscovite, and rare spinel and sillimanite were observed (P1ate $1 \mathrm{~b}$ ). The andalusite commonly exhibit intense pleochroism ( $\tau$ pink-mauve, $\alpha$ colourless) and a well developed muscovite (sericitic) alteration rim. Some andalusite has been completely pseudomorphed by sericite, whereas others only display sericitic replacement of crystal cores (donut texture). Irregular islands of andalusite, together with cordierite and rare $\mathrm{K}$-feldspar, also occur within large ragged laths of muscovite.

Andalusite can also be associated with pyrite and other sulphides which occupy voids and fractures and partially envelope the crystals (Plate 1c).

Microprobe analyses (Table 2) indicate that andalusite is not a pure phase. The most abundant impurity is $\mathrm{FeO}_{\mathrm{T}}$, probably $\mathrm{Fe}^{3+}$ as it substitutes for $\mathrm{Al}^{3+}$ forming the complex ( $\mathrm{FeAl}$ ) $\mathrm{Si}_{2} \mathrm{O}_{5}$ (Grambling and Williams, 1985). The andalusite displays a strong $\mathrm{Fe}$ zonation (Fig. 3), with cores containing considerably more $\mathrm{FeO}_{\mathrm{T}}$ than the rims (0.54-1.99 wt.\% vs $0.41-0.61$ wt.\% $\left.\mathrm{FeO}_{\mathrm{T}}\right)$. Other impurities within the andalusite include $\mathrm{CaO}, \mathrm{K}_{2} \mathrm{O}, \mathrm{MgO}, \mathrm{MnO}$ and $\mathrm{Na}_{2} \mathrm{O}$. These impurities are present in very $10 \mathrm{w}$ concentrations and exhibit no zonation with the most abundant being $\mathrm{MnO}(\leq 0.11 \mathrm{wt} . \%)$ and $\mathrm{Na}_{2} \mathrm{O}$ $(\leq 0.07 \mathrm{wt} . \%)$. 
Table 1. Summary of the textural and phase relationships of the principle mineral phases within the HAHA zone.

\begin{tabular}{|c|c|c|c|c|}
\hline MINERAL & CO-EXISIINC ASSEMBLACE & PETROGRAPHIC VARIEIIES & INCLUSIONS & AL TFRATIIIN \\
\hline SILL IMANIIE & $\begin{array}{l}+ \text { andalusite } \\
+ \text { K-feldspar } \\
+ \text { plagioclase } \\
+ \text { biotite } \\
+ \text { muscovite }\end{array}$ & $\begin{array}{l}\text { - small }(<1 \mathrm{~mm}) \text { euhedral crystals } \\
\text { in K-feldspar and plagioclase } \\
\text { acicular masses of fibrolite } \\
\text { fibrolite crystals in biot ite and } \\
\text { muscovite laths } \\
\text {. small acicular crystals in andalusite }\end{array}$ & none & $\begin{array}{l}\text { - polymorphic replacement by andalusite } \\
\text { - pseudomorphic replacement of /by biot ile and } \\
\text { muscovile indicat ed by peculiar fibrous hahite of micas }\end{array}$ \\
\hline ANDALIISITE: & \begin{tabular}{|l} 
+ sillimanite \\
+ muscovite (sericite) = biotite \\
+ cordierite = muscovite \\
k-feldspar + plagioclase $=$ albite \\
+ spinel \\
+ sulphides (pyrite $=$ sphalerite \\
$\quad=$ chalcopyrite + covellite)
\end{tabular} & $\begin{array}{l}\text {-anhedral crystals in muscovite and } \\
\text { biotite laths } \\
\text { anhedral crystals rimmed by pinitized } \\
\text { cordierite } \\
\text { euhedral crystals surrounded by halo } \\
\text { of pot assic feldspar and intermediate } \\
\text { to albit ic feldspar } \\
\text { euhedral crystals mant led and replaced } \\
\text { by sericite } \\
\text { complete replacement of crystal core } \\
\text { by spherical mass of sericite creat es } \\
\text { a donut like appearance }\end{array}$ & \begin{tabular}{|l} 
- sillimanite \\
spinel \\
biotite \\
- muscovite (sericite) \\
- albite
\end{tabular} & $\begin{array}{l}\text { - sericite manl les surrounding cryslals } \\
\text { - partial to complete replacement of cryst als by muscovite } \\
\text { (sericile) } \\
\text { andalusite islands in large euhedral laths of secondary } \\
\text { muscovite } \\
\text { - pseudomorphic replacement by muscovite } \\
\text { partial to complete replacement of cyrstals by pinitizen } \\
\text { cordierite }\end{array}$ \\
\hline CORDIERIIE & $\begin{array}{l}+ \text { andalusite - muscovite } \\
+ \text { biot ite }\end{array}$ & $\begin{array}{l}\text { - anhedral pinitized blebs with andalusite } \\
\text { together forming islands in secondary } \\
\text { muscovite laths } \\
\text { - pinitized amorphous mass rimming } \\
\text { ondalusites } \\
\text {. pinitized crystals with biot ite laths }\end{array}$ & none & - pinite \\
\hline HERCYNITIC SPINEL & + andalusite & $\begin{array}{l}\text { - anhedral grains occuppying core of } \\
\text { andalusite crystals }\end{array}$ & none & none \\
\hline
\end{tabular}

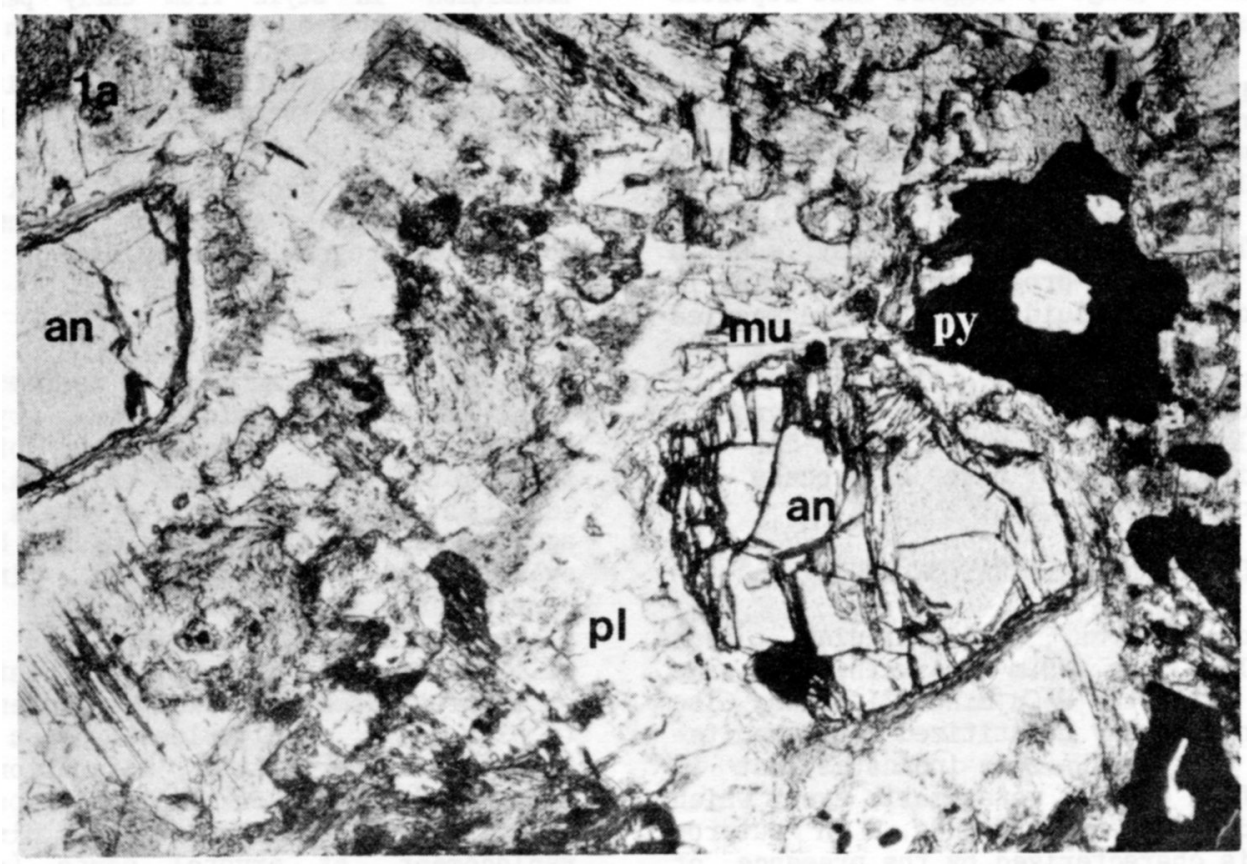

Plate 1a. Andalusite crystals surrounded by bleached halo composed of oligoclase $\left(\mathrm{An}_{11}-\mathrm{An}_{16}\right)_{\text {. Clustered around the }}$ perimeter are masses of pinite and biotite. Field of view is $1 \mathrm{~mm}$. an: andalusite, mu: muscovite, p1: plagioclase, py: pyrite.

\section{Sillimanite}

This mineral phase is most commonly observed as small (1-3 mm), euhedral crystal clusters and basal sections within laths of biotite and muscovite (Plate 1d). Sillimanite is more rarely seen as inclusions within plagioclase feldspar and andalusite.

Compared to andalusite, sllilmanite contains less $\mathrm{FeO}_{\mathrm{T}}(0.18-0.59 \mathrm{wt} . \%)$ but similar concentrations of $\mathrm{CaO}, \mathrm{Na}_{2} \mathrm{O}$ and $\mathrm{K}_{2} \mathrm{O}$ (Table 2). No chemical zonation was observed.

\section{Spinel}

This mineral phase occuples the cores of andalusite crystals (P1ate $1 \mathrm{~b}$ ) as dark emerald green anhedral crystals which have been identified as hercynite-rich spinel ( $\left.\mathrm{FeZnAl}_{2} \mathrm{O}_{4}\right)$. The spinels are iron-rich (27.64-29.27 wt. $\left.\% \mathrm{FeO}_{\mathrm{T}}\right)$, contain significant amounts of $\mathrm{ZnO}(10.9-12.38$ Wt.\%), with minor MnO (0.85-1.01 wt.\%) and $\mathrm{MgO}$ (0.55-0.69 wt.\%) (Table 3).

\section{Cordierite}

Light to dark brown, amorphous, pinitized cordlertte commonly mantles and pseudomorphs andalusite crystals. Cordierite also occurs with spherical masses of sericite which may represent completely altered andalusite. Small (<1 mm) intergrowths of pinitized cordierite and chloritized biotite also occur. The pinitized 


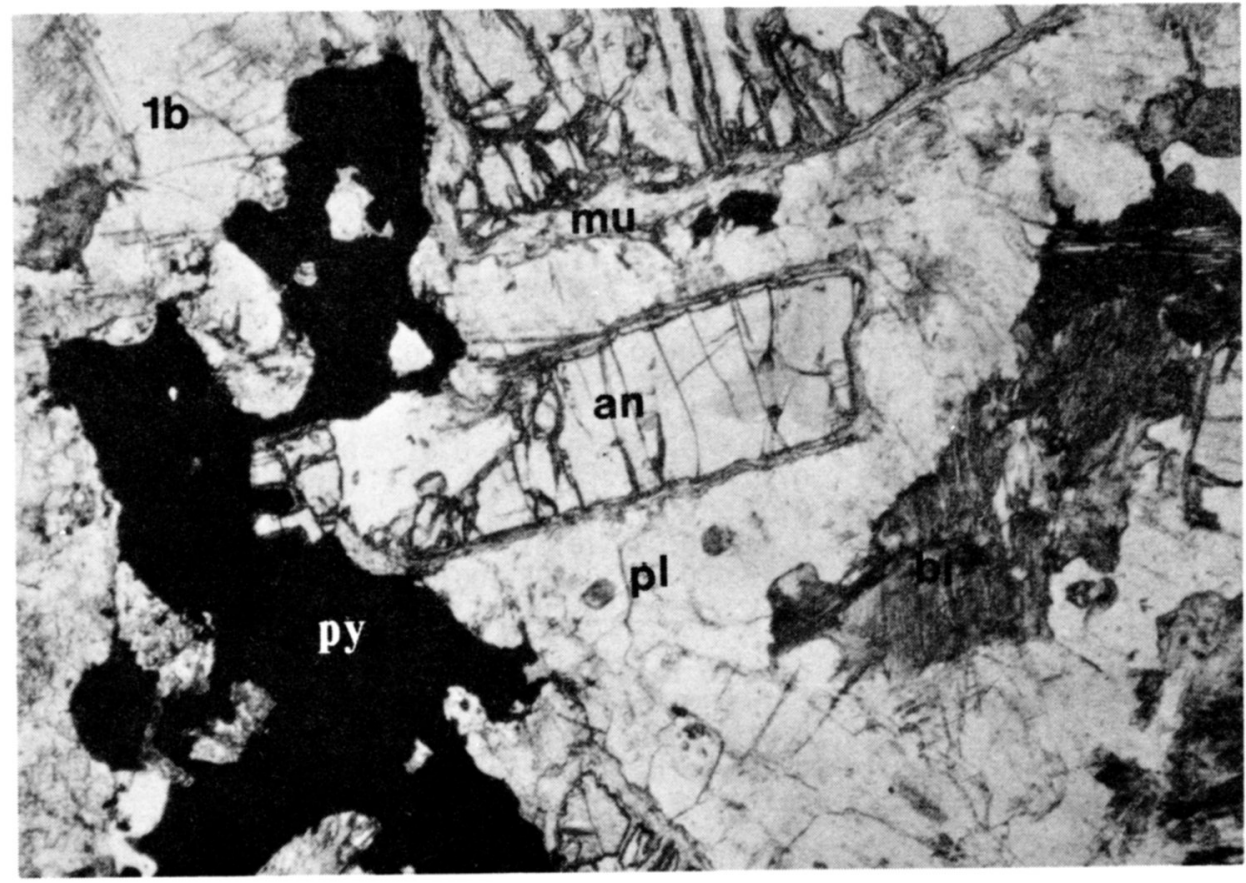

Plate 1b. Euhedral andalusite crystal exhibiting a sericitic alteration rim and feldspar halo is partially enveloped by late-stage pyrite (opaque). Field of view is $1 \mathrm{~mm}$.

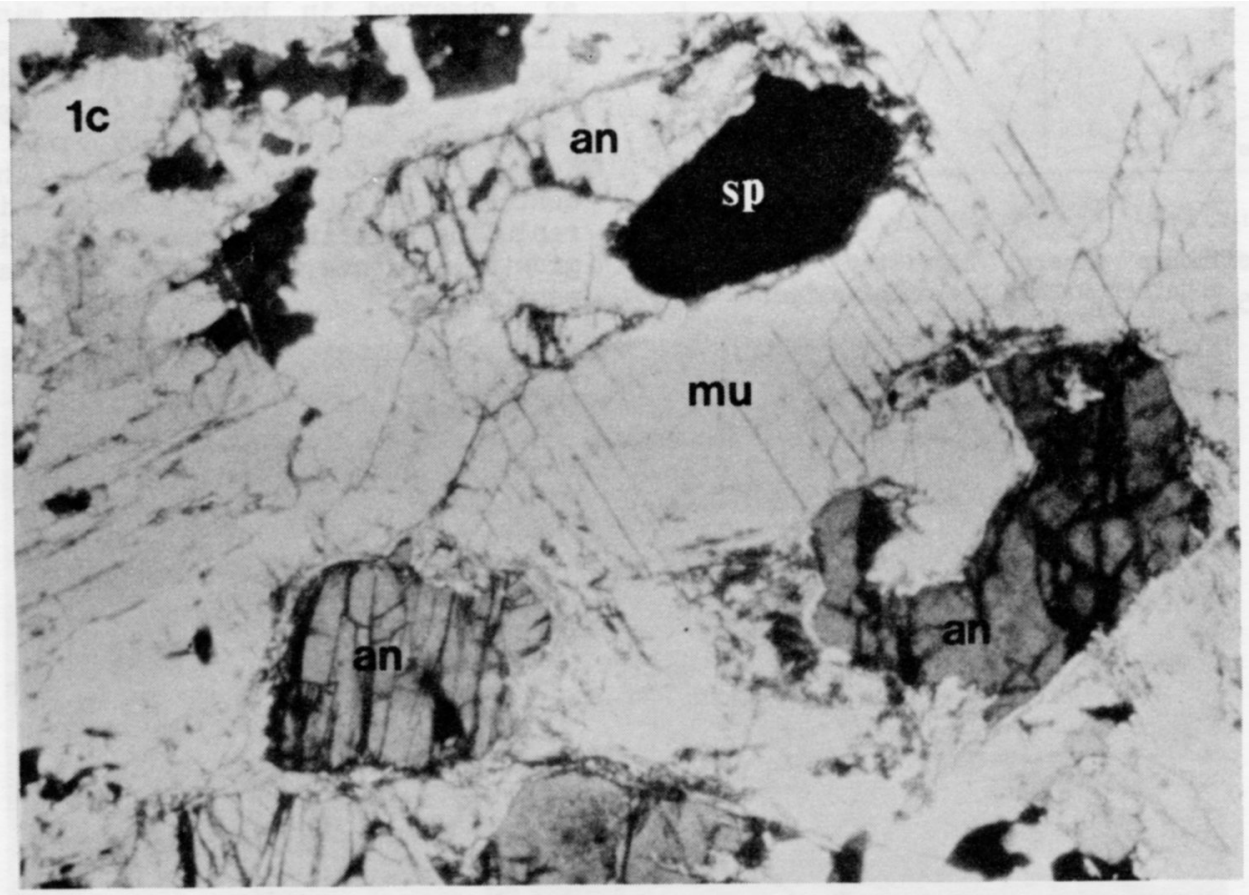

Plate 1c. Sma1l $(<1 \mathrm{~mm}$ ) hercynite-spine1 grain (isotropic) occupying core of andalusite crystal. Fle1d of view is 0.4 mm. sp: spine1

nature of the cordierite did not allow reliable microprobe analyses.

\section{Muscovite}

Muscovite observed within the HAHA zone is obviously secondary, and occurs as several textural types, including (1) sericitic mantles surrounding andalusite, (2) laths of muscovite containing andalusite and cordierite islands, (3) pseudomorphs of both sillimanite and andalusite, and (4; irregular laths replacing biotite and sillimanite ( \pm fibrolite) intergrowths. The micas commonly display a peculiar fibrous habit which may indicate pseudomorphic replacement of sillimanite.

The white mica is essentially a pure end member 
Table 2. Representative microprobe analyses of aluminosilicates from the HAHA zone. A rim-core pair represent analyses from a single crystal.

\begin{tabular}{lrrrrrrr}
\hline & $1 \mathrm{R}$ & $1 \mathrm{C}$ & $2 \mathrm{R}$ & $2 \mathrm{C}$ & 3 & 4 & 5 \\
\hline $\mathrm{SiO}_{2}$ & 32.32 & 36.88 & 36.94 & 36.85 & 36.28 & 36.38 & 36.64 \\
$\mathrm{A1}_{3}{ }_{3}$ & 62.09 & 61.39 & 62.74 & 62.92 & 63.31 & 63.49 & 62.86 \\
$\mathrm{THO}_{2}$ & 0.07 & 0.02 & 0.00 & 0.00 & 0.00 & 0.00 & 0.00 \\
$\mathrm{FeO}_{\mathrm{T}}$ & 0.55 & 1.18 & 0.42 & 1.01 & 0.31 & 0.53 & 0.38 \\
$\mathrm{MnO}^{2}$ & 0.00 & 0.04 & 0.00 & 0.00 & 0.00 & 0.00 & 0.00 \\
$\mathrm{MgO}$ & 0.00 & 0.06 & 0.02 & 0.11 & 0.01 & 0.01 & 0.01 \\
$\mathrm{CaO}$ & 0.00 & 0.00 & 0.04 & 0.02 & 0.04 & 0.03 & 0.06 \\
$\mathrm{Na}_{2} \mathrm{O}$ & 0.04 & 0.02 & 0.07 & 0.05 & 0.05 & 0.00 & 0.06 \\
$\mathrm{~K}_{2} \mathrm{O}$ & 0.00 & 0.00 & 0.02 & 0.01 & 0.03 & 0.03 & 0.00 \\
$\mathrm{TOTAL}$ & 100.06 & 99.57 & 100.24 & 100.96 & 100.03 & 100.47 & 100.00
\end{tabular}

1,2: $\operatorname{rim}(R)$ and core(C) sets of andalusites; all occur as euhedral cyrstals with muscovite mantles

4: sillimantte in oligoclase

5: sillimanite (overgrowths?) coexisting with biotite

6: sillimanite coexisting with oligoclase and biotite

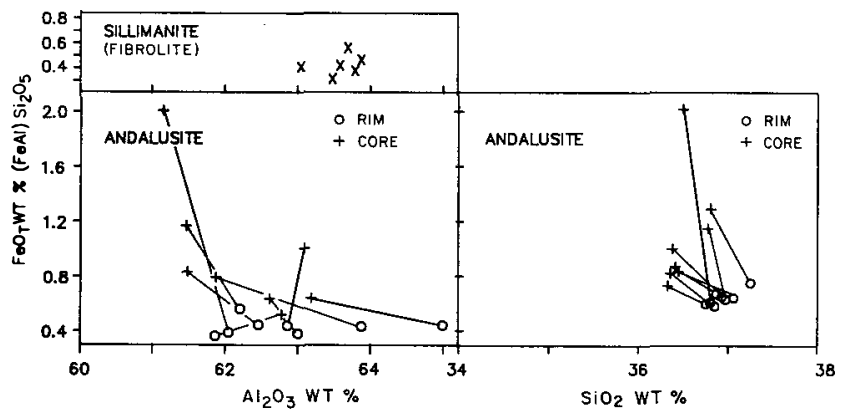

Fig. 3. Aluminosilicate mineral chemistry; note the strong ( $\mathrm{FeAl}) \mathrm{Si}_{2} \mathrm{O}_{5}$ zonation within the andalusites. muscovite (Fig. 4, Table 4) with a minor amount cf phengitic substitution (atomic prop. S1-3.02-3.16) as observed in hydrothermal mineral deposits elsewhere within the SMB (Strong and Chatterjee, 1985). Muscovite also exhibits a higher concentration of $\mathrm{K}_{2} \mathrm{O}$ wt.\% (10.9-11.5) compared to those elsewhere within the BIPI suite (average 9.5; Kontak and Corey, in press). The highest $\mathrm{K}_{2} \mathrm{O}$ contents $(\approx 11.0 \mathrm{wt} . \%)$ are found within muscovite replacing biotite-sililmanite ( \pm fibrolite) intergrowths and ones which appear to pseudomorph sil11manite.

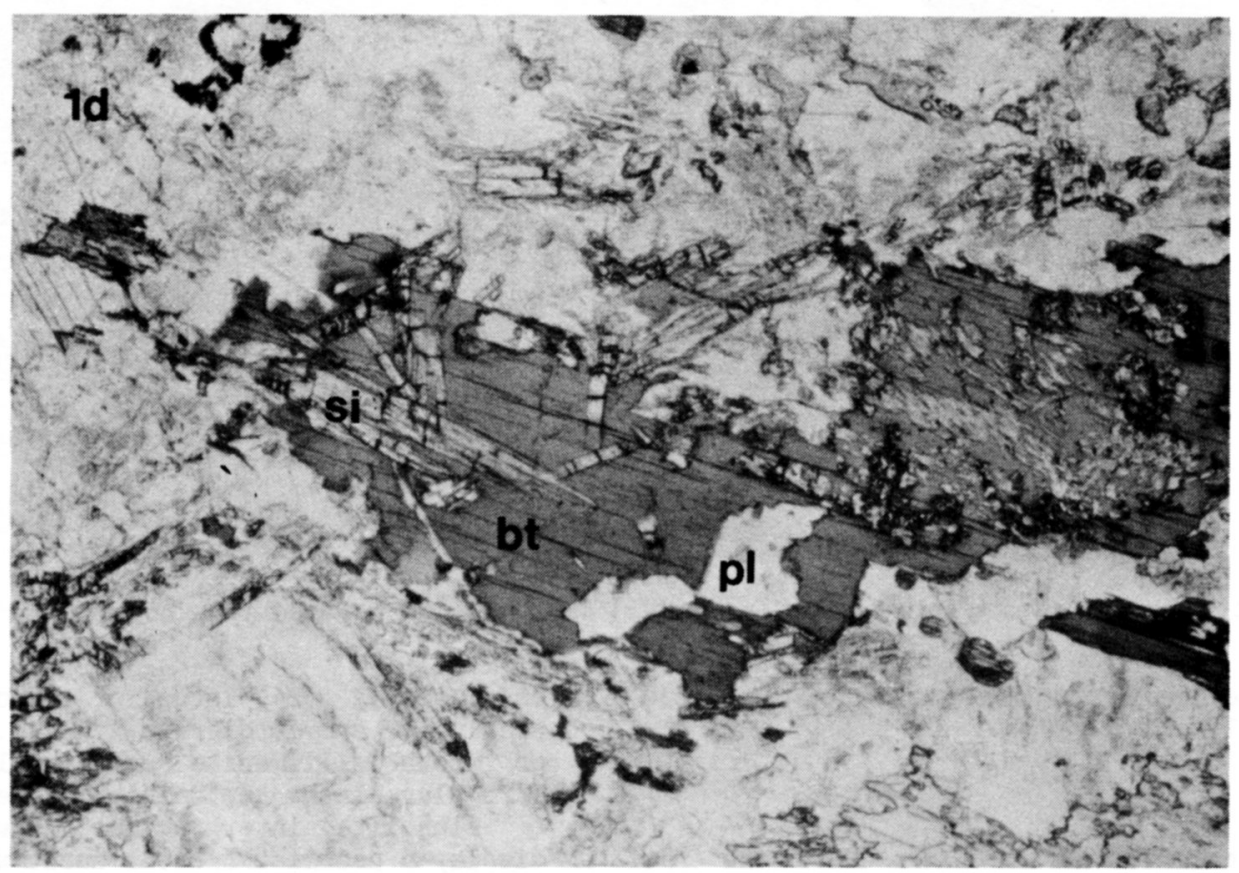

Plate 1d. Large flake of secondary biotite containing abundant sillimanite (fibrolite) crystals. Note that the sillimanite is not confined to the biotite. Field of view $1 \mathrm{~s} 0.4 \mathrm{~mm}$. si: sillimanite, b1: biotite. 
Table 3. Representative microprobe analyses of spinel from the HAHA zone.

\begin{tabular}{lrrr}
\hline & 1 & 2 & \multicolumn{1}{c}{3} \\
\hline $\mathrm{Al}_{2} \mathrm{O}_{3}$ & 57.53 & 57.98 & 57.09 \\
$\mathrm{FeO}^{3}$ & 27.64 & 27.84 & 29.27 \\
$\mathrm{ZnO}^{\mathrm{T}}$ & 12.38 & 11.54 & 10.90 \\
$\mathrm{MnO}$ & 1.01 & 0.92 & 0.85 \\
$\mathrm{MgO}$ & 0.55 & 0.55 & 0.69 \\
$\mathrm{~T} 10{ }_{2}$ & 0.09 & 0.03 & 0.08 \\
TOTAL & 99.20 & 99.85 & 99.87 \\
\hline
\end{tabular}

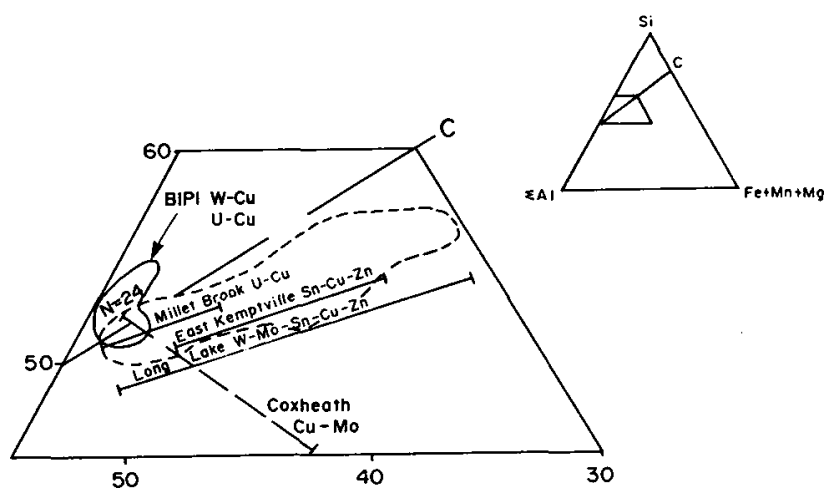

F1g. 4. Muscovite compositions from the HAHA zone plotted in the $\Sigma A 1-S 1-(F e+M n+M G)$ diagram (modifled from Kontak and Corey, in press). Analyses are compared to muscovites analyzed by Strong and Chatterjee (1985) from other hydrothermal mineral deposits within Nova Scotia (enclosed by heavy dashed line).

\section{Biotite}

This mineral is not an abundant phase within the HAHA zone and commonly occurs as anhedral chloritized flakes which exhibit varying degrees of muscovite replacement. Anhedral, dark brown laths were also observed coexisting with sillimanite and intergrown with cordierite as small clots. Biotite rarely occurs as an inclusion within andalusite.

With the exception of the HAHA zone analyses, biotite shows a progressive enrichment in $\mathrm{FeO}_{\mathrm{T}}$ and $\mathrm{Al}_{2} \mathrm{O}_{3}$ wt.\% and depletion in $\mathrm{K}_{2} \mathrm{O}, \mathrm{Na} 2 \mathrm{O}, \mathrm{TiO}_{2}$ and $\mathrm{MgO}$ wt.\% from granodiorite to microgranite (Fig. 5 , Table 5); Mn0 wt.\% exhibits only a slight depletion. Biotite from the HAHA zone deviates from the above trends by being depleted in $\mathrm{FeO}_{\mathrm{T}}$ and enriched in $\mathrm{MnO}, \mathrm{MgO}, \mathrm{K}_{2} \mathrm{O}$, and $\mathrm{Na}_{2} \mathrm{O}$ wt.\% compared to biotite from the microgranite phase of the BIPI suite. The $A 1$ versus $\mathrm{T} 1$ cationic plot for biotite (Fig. 6) displays a trend of decreasing $\mathrm{T} 1$ (0.44-0.06) and increasing $\mathrm{A} 1^{\mathrm{I}}(0.42-1.36)$ from the granodiorite to HAHA zone.

Biotite from the microgranite phase contain the highest $\mathrm{Fe} /(\mathrm{Fe}+\mathrm{Mg})$ ratios $(0.87)$, with those from the HAHA zone and biotite granodiorite xenoliths containing lower ratios $(0.8$ and 0.62 respectfully; Fig. 7). Biotite from the microgranite and HAHA zone has a higher ratio when compared to the field for peraluminous granites (Clarke, 1981) but are similar in their Fe enrichment compared to other hydrothermal systems within the SMB (Strong and Chatterjee, 1985).

\section{Feldspars}

Oligoclase is the most common plagioclase observed within the HAHA zone and occurs as a halo surrounding andalusite-muscovite intergrowths. These haloes are of two types: (1) a optically continuous crystal in which andalusite appears to have replaced the plagioclase core, and (2) a feldspar mosaic composed of several crystals. This latter type, although comprised predominately of oligoclase, may contain finely twinned albite. Albite also occurs as inclusions within andalusite. Minor orthoclase occurs as small blebs within albite and oligoclase suggesting it is a product of later $\mathrm{K}$-feldspathization.

Figure 8 compares feldspar hosting andalusite crystals within the zone of HAHA to the fields defined by Kontak and Corey (in press) for feldspar seen elsewhere within the BIPI suite. The majority of feldspar from the HAHA zone is oligoclase $\left(\mathrm{An}_{8-16}\right)$, although albitic $\left(\mathrm{An}_{\mathrm{O}-9}\right)$ and potassic $\left(0 r^{8-16}\right.$ ) feldspars are present (Table 6). It is evidene that a strong compositional similarity exists between these feldspars and those from monzogranite of the BIPI suite.

\section{Apatite}

Apatite is light-green in colour and ranges in size from 2-5 mm. It overgrows all other minerals phases and thus appears to have been the last mineral to crystallize. A Pb-P mineral (pyromorphite?) was observed as a fracture filling within the apatites. In Table 7 the composition of secondary apatites from the HAHA zone and Phase 1 of the BIPI suite are presented and compared to primary apatite occurring as inclusions within biotite from granodiorite xenoliths. It is apparent that while they all contain similar levels of $F$, the secondary apatites are significantly enriched in $\mathrm{Mn}, \mathrm{C} 1, \mathrm{Fe}$ and depleted in $\mathrm{Ca}$. Furthermore, the apatite from the HAHA zone displays an enrichment in $\mathrm{F}$ and $\mathrm{Fe}$ and depletion in Mn from core to rim.

\section{DISCUSSION}

\section{Interpretation of Mineral Chemistry}

\section{Aluminosilicates}

As mentioned above, the andalusite is characterized by intense pleochroism reflecting a strong iron ( $\mathrm{Fe}^{3+}$ ) zonation. Grambling and Williams (1985), who studied aluminosilicates from Precambrian metamorphic rocks of northern New Mexico, suggest that the ability of andalusite to absorb iron is a function of pressure, temperature and oxygen fugacity; a decrease in pressure and/or increase in temperature and oxygen fugacity permits greater $\mathrm{Fe}^{3 f}$ uptake. The strong $\mathrm{Fe}$ enrichment within the cores of andalusites in the HAHA zone would imply that these parameters changed during crystallization of andalusite. Previous studies of andalusite from the SMB (Clarke et al., 1976) and its thermal metamorphic aureole (Jamieson, 1974) indicated some $\mathrm{Fe}^{3+}$ substitution 
Table 4. Representative microprobe analyses of muscovite from the HAHA zone. Structural formulae based on 220.

\begin{tabular}{|c|c|c|c|c|c|c|c|c|}
\hline & 1 & 2 & 3 & 4 & 5 & 6 & 7 & 8 \\
\hline $\begin{array}{l}\mathrm{SiO}_{2} \\
\mathrm{Al}_{2} \mathrm{O}_{3} \\
\mathrm{~T} \mathrm{O}_{2} \\
\mathrm{FeO}_{\mathrm{T}} \\
\mathrm{MnO}^{\mathrm{T}} \\
\mathrm{MgO} \\
\mathrm{CaO} \\
\mathrm{Na}_{2} \mathrm{O} \\
\mathrm{K}_{2} \mathrm{O} \\
\mathrm{TCTAL}\end{array}$ & $\begin{array}{r}46.26 \\
35.84 \\
0.00 \\
1.22 \\
0.06 \\
0.34 \\
0.02 \\
0.46 \\
11.27 \\
95.45\end{array}$ & $\begin{array}{r}46.00 \\
36.48 \\
0.00 \\
1.08 \\
0.06 \\
0.22 \\
0.00 \\
0.41 \\
11.53 \\
95.78\end{array}$ & $\begin{array}{r}46.12 \\
36.59 \\
0.00 \\
1.56 \\
0.05 \\
0.29 \\
0.00 \\
0.89 \\
10.91 \\
96.41\end{array}$ & $\begin{array}{r}45.68 \\
35.31 \\
0.07 \\
1.75 \\
0.00 \\
0.46 \\
0.00 \\
0.86 \\
10.94 \\
95.07\end{array}$ & $\begin{array}{r}44.86 \\
36.89 \\
0.02 \\
0.84 \\
0.01 \\
0.12 \\
0.02 \\
0.40 \\
11.19 \\
94.35\end{array}$ & $\begin{array}{r}45.75 \\
35.36 \\
0.28 \\
1.51 \\
0.11 \\
0.37 \\
0.03 \\
0.66 \\
10.37 \\
94.44\end{array}$ & $\begin{array}{r}48.19 \\
35.34 \\
0.02 \\
1.60 \\
0.06 \\
0.20 \\
0.00 \\
0.46 \\
10.24 \\
96.11\end{array}$ & $\begin{array}{r}46.34 \\
35.94 \\
0.08 \\
1.14 \\
0.00 \\
0.30 \\
0.03 \\
0.58 \\
11.07 \\
95.48\end{array}$ \\
\hline $\begin{array}{l}\mathrm{Si} \\
\mathrm{A} 1 \\
\mathrm{~A} 1 \\
\mathrm{vi} \\
\mathrm{T} 1 \\
\mathrm{Fe} \\
\mathrm{Mn} \\
\mathrm{Mg} \\
\mathrm{Ca} \\
\mathrm{Na} \\
\mathrm{K}\end{array}$ & $\begin{array}{l}6.163 \\
1.837 \\
3.790 \\
0.000 \\
0.136 \\
0.007 \\
0.068 \\
0.003 \\
0.119 \\
1.915\end{array}$ & $\begin{array}{l}6.113 \\
1.887 \\
3.826 \\
0.000 \\
0.120 \\
0.007 \\
0.044 \\
0.000 \\
0.106 \\
1.954\end{array}$ & $\begin{array}{l}6.092 \\
1.908 \\
3.788 \\
0.000 \\
0.172 \\
0.006 \\
0.057 \\
0.000 \\
0.288 \\
1.838\end{array}$ & $\begin{array}{l}6.133 \\
1.867 \\
3.719 \\
0.007 \\
0.196 \\
0.000 \\
0.092 \\
0.000 \\
0.224 \\
1.873\end{array}$ & $\begin{array}{l}6.039 \\
1.961 \\
3.891 \\
0.002 \\
0.095 \\
0.001 \\
0.024 \\
0.003 \\
0.104 \\
1.921\end{array}$ & $\begin{array}{l}6.151 \\
1.849 \\
3.752 \\
0.028 \\
0.170 \\
0.013 \\
0.074 \\
0.004 \\
0.172 \\
1.778\end{array}$ & $\begin{array}{l}6.327 \\
1.673 \\
3.794 \\
0.002 \\
0.176 \\
0.007 \\
0.039 \\
0.000 \\
0.117 \\
1.715\end{array}$ & $\begin{array}{l}6.163 \\
1.837 \\
3.796 \\
0.008 \\
0.127 \\
0.000 \\
0.059 \\
0.004 \\
0.150 \\
1.878\end{array}$ \\
\hline
\end{tabular}

fibrous muscovite (pseudomorphing sillimanite ?): 1,2 secondary lath containing sillimanite: 8 secondary lath containg andalusite + cordierite: 5,6 mantle around andalusite: $3,4,7$
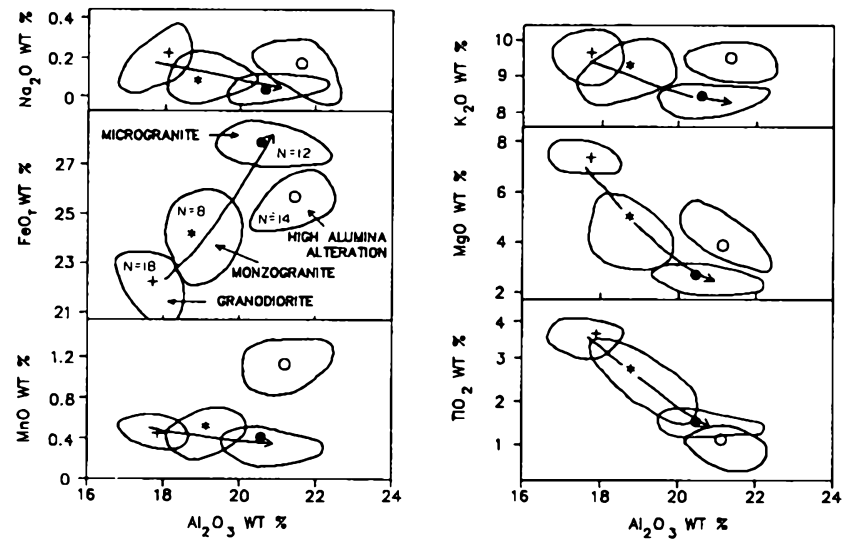

F1g. 5. Oxide wt.\% contents of biotites from units of the BIPI suite versus their $\mathrm{Al}_{2} \mathrm{O}_{3}$ wt.\%. Symbol location represents average analyses fol units, whereas variation within each unit is denoted by circle surrounding symbol. Arrows represent assumed magmatic/metasomatic trends.

with $\mathrm{FeO}_{\mathrm{T}}$ concentrations of $0.45 \pm 0.17 \mathrm{wt} . \%$ and $0.81 \pm 0.83 \mathrm{wt} . \%$, respective1y. Although no zonation was reported, Clarke et al. (1976). indicated that some andalusite exhibited colourless to pink

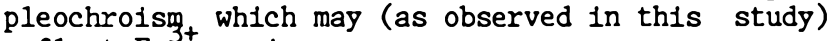
reflect $\mathrm{Fe}^{3+}$ zoning.

Although andalusite is the most abundant phase, the presence of the mineral assemblages sillimanite-oligoclase, sillimanite-andalusite, and sililmanite-biotite indicate that the fluids attending metasomatism were initially above the andalusite stability field $\left(620^{\circ} \mathrm{C}\right.$ \& $2 \mathrm{~kb}$; Robie and

Hemingway, 1984). Equilibration with lower temperature fluids is indicated by the presence of abundant secondary muscovite surrounding and replacing andalusite.

\section{Spine1}

The presence of spine1 (hercynite inclusions in andalusite) within the HAHA zone implies an environment characterized by high temperature, low silica activity and high oxygen fugacity (Clarke, 1981). The only previous documented occurrence of spinel within the SMB was by Farley (1979), who mentioned the presence of $\leq 5 \mathrm{~mm}$ cubes and disseminations of gahnite-rich spine1 (25.32 wt.\% $\mathrm{ZnO} ; \quad 18.74$ wt.\% $\quad \mathrm{FeO}_{\mathrm{T}}$ ) within a greisenized pegmatite and aplite. Spry (1987), in describing compositional zonation in gahnite spinels worldwide, Indicated that hercynite is stabilized to lower temperatures $\left(<750^{\circ} \mathrm{C}\right)$ by $\mathrm{Zn}$ in the presence of quartz.

\section{Muscovite}

Experimental studies by Monier and Robert (1986) have determined that increasing phengitic and biotitic substitution in muscovite reflects decreasing crystallization temperatures. Comparison of the BIPI suite data to the Monier and Robert (1986) cation diagram (Fig. 9) indicates that hydrothermal muscovite within the HAHA zone and BIPI suite granitolds crystallized at high temperatures $\left(\geq 500^{\circ} \mathrm{C}\right.$ at $2 \mathrm{~kb}$; Monfer and Robert, 1986). This is consistent with the presence of the mineral 
Table 5. Representative microprobe analyses of biotite from the BIPI suite and HAHA zone. Structural formulae based on 220 .

\begin{tabular}{|c|c|c|c|c|c|c|c|c|}
\hline & 21 & 22 & 23 & 24 & 25 & 26 & 27 & 28 \\
\hline 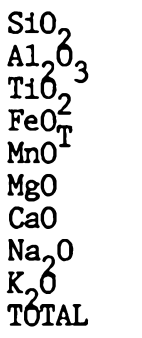 & $\begin{array}{r}34.35 \\
21.16 \\
1.16 \\
25.58 \\
1.18 \\
3.65 \\
0.00 \\
0.06 \\
9.43 \\
96.56\end{array}$ & $\begin{array}{r}34.28 \\
21.36 \\
0.93 \\
25.56 \\
1.05 \\
3.69 \\
0.05 \\
0.06 \\
9.84 \\
96.82\end{array}$ & $\begin{array}{r}34.24 \\
21.78 \\
0.56 \\
25.25 \\
1.08 \\
3.77 \\
0.00 \\
0.21 \\
9.02 \\
95.89\end{array}$ & $\begin{array}{r}34.35 \\
21.33 \\
0.58 \\
25.62 \\
1.29 \\
3.84 \\
0.02 \\
0.28 \\
9.44 \\
96.75\end{array}$ & $\begin{array}{r}33.65 \\
21.73 \\
1.56 \\
26.26 \\
0.45 \\
3.20 \\
0.00 \\
0.28 \\
9.61 \\
96.73\end{array}$ & $\begin{array}{r}34.51 \\
22.30 \\
1.01 \\
25.22 \\
1.29 \\
3.11 \\
0.00 \\
0.01 \\
9.44 \\
96.87\end{array}$ & $\begin{array}{r}35.66 \\
20.40 \\
1.79 \\
22.40 \\
0.95 \\
5.56 \\
0.00 \\
0.22 \\
9.50 \\
96.47\end{array}$ & $\begin{array}{r}34.35 \\
21.05 \\
1.18 \\
25.18 \\
0.90 \\
3.65 \\
0.02 \\
0.21 \\
9.29 \\
95.83\end{array}$ \\
\hline $\begin{array}{l}\mathrm{Si} \\
\mathrm{A} 1 \\
\mathrm{~A} 1 \mathrm{iv} \\
\mathrm{Ti} 1 \\
\mathrm{Fe} \\
\mathrm{Mn} \\
\mathrm{Mg} \\
\mathrm{Ca} \\
\mathrm{Na} \\
\mathrm{K}\end{array}$ & $\begin{array}{l}5.331 \\
2.669 \\
1.200 \\
0.135 \\
3.320 \\
0.155 \\
0.844 \\
0.000 \\
0.018 \\
1.867\end{array}$ & $\begin{array}{l}5.315 \\
2.685 \\
1.218 \\
0.108 \\
3.314 \\
0.138 \\
0.853 \\
0.008 \\
0.018 \\
1.946\end{array}$ & $\begin{array}{l}5.326 \\
2.674 \\
1.318 \\
0.066 \\
3.284 \\
0.142 \\
0.874 \\
0.000 \\
0.063 \\
1.789\end{array}$ & $\begin{array}{l}5.328 \\
2.672 \\
1.226 \\
0.068 \\
3.323 \\
0.169 \\
0.888 \\
0.003 \\
0.084 \\
1.867\end{array}$ & $\begin{array}{l}5.229 \\
2.771 \\
1.207 \\
0.182 \\
3.412 \\
0.059 \\
0.741 \\
0.000 \\
0.084 \\
1.905\end{array}$ & $\begin{array}{l}5.316 \\
2.684 \\
1.364 \\
0.117 \\
3.249 \\
0.168 \\
0.714 \\
0.000 \\
0.003 \\
1.855\end{array}$ & $\begin{array}{l}5.441 \\
2.559 \\
1.109 \\
0.205 \\
2.858 \\
0.123 \\
1.264 \\
0.000 \\
0.065 \\
1.849\end{array}$ & $\begin{array}{l}5.355 \\
2.645 \\
1.223 \\
0.138 \\
3.283 \\
0.119 \\
0.848 \\
0.003 \\
0.063 \\
1.847\end{array}$ \\
\hline $\mathrm{Fe} / \mathrm{Fe}+\mathrm{Mg}$ & 0.797 & 0.795 & 0.790 & 0.789 & 0.821 & 0.819 & 0.694 & 0.794 \\
\hline
\end{tabular}

22,23,26: coexist with sillimanite and plagioclase

21: contains andalusite

25,27: are inclusions within andalusite

24,29: seperate grains

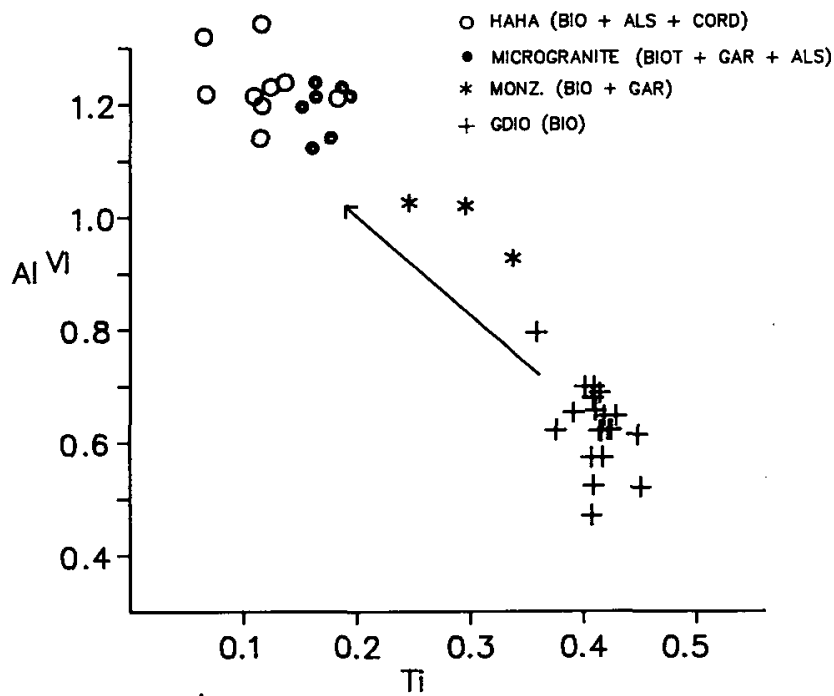

F1g. 6. $A 1^{\text {V1 }}$ versus $T 1$ plot (adapted from LeBe1, 1979). for blotites from the BIPI sulte. Arrow shows decreasing temperature of biotite crystallization.

assemblage muscovite-andalusite-albite which. according to thermodynamic studies by Helgeson (1985), Indicates a temperature of $<600^{\circ} \mathrm{C}$ at $2 \mathrm{~kb}$.

\section{Biotite}

A trend of decreasing $\mathrm{T} 1$ has been reported by a

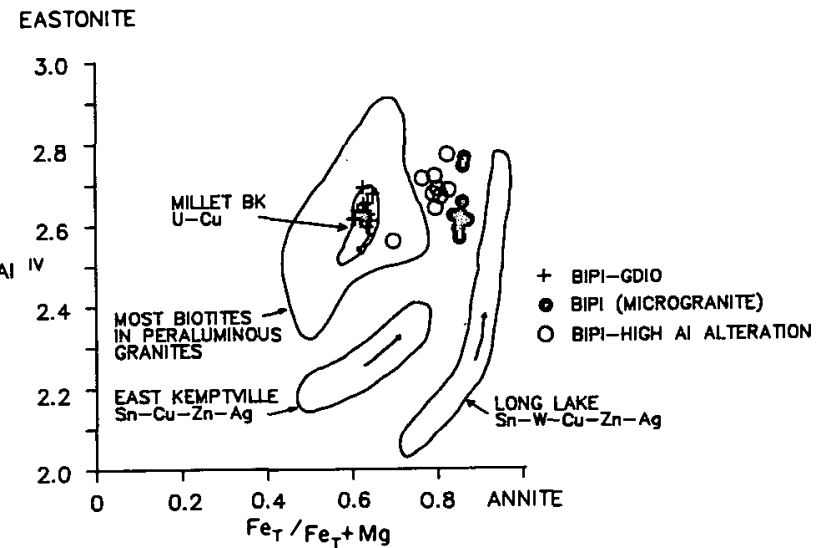

Fig. 7. $\mathrm{Al}^{\mathrm{IV}}$ over $\mathrm{Fe} /(\mathrm{Fe}+\mathrm{Mg})$ plot for biotites from the BIPI suite. Comparisons are made to Clarke's (1981) field for blotites in peraluminous granites and also those defined by Strong and Chatterjee (1985) for biotites from other hydrothermal mineral deposits within the SMB.

number of authors for hydrothermal biotites from several porphyry copper deposits (e.g., Le Bel, 1979; Jacobs and Perry, 1979; Bowman et al., 1987). Similarly, a study by Dilles (1987) of biotite within alteration zones associated with porphyry copper mineralization within the Yerington Batholith suggests that an increase in $\mathrm{T} i$ reflects an increase in equilibration temperature. Thus the 


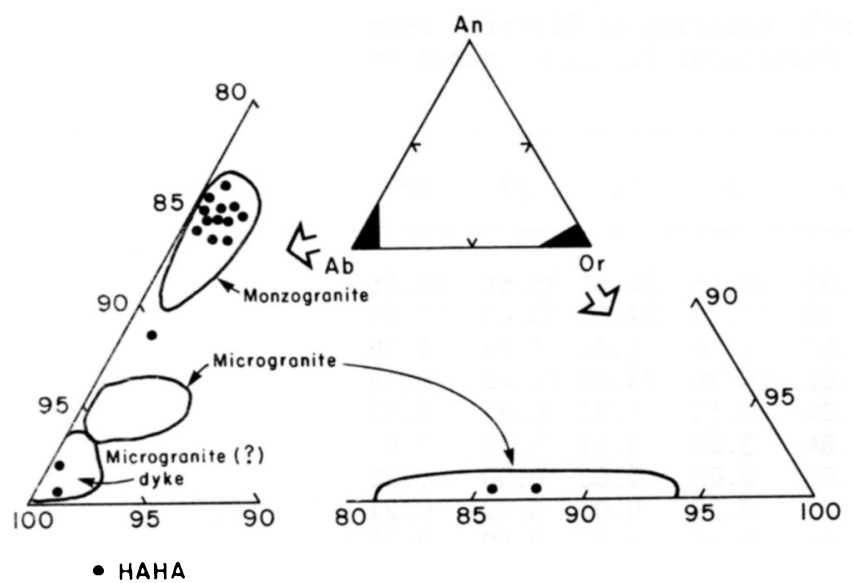

Fig. 8. Composition of feldspars from the HAHA zone (solid dots) plotted in the An-Ab-Or diagram. Data is compared to fields delineated by Kontak and Corey (in press) for several units of the BIPI suite.

lower contents for blotite from the HAHA zone suggests that these micas equilibrated at lower temperatures than biotites in the units of the BIPI suite.

The lower $\mathrm{Fe} /(\mathrm{Fe}+\mathrm{Mg})$ ratio in biotite from the HAHA zone compared to biotite from the microgranite can probably be attributed to a combination of fluld chemistry, lower temperature, and higher oxygen fugacity. The latter would account for the $\mathrm{Mg}$-enrichment in biotite from the HAHA zone.

\section{Feldspars}

The feldspar haloes surrounding andalusitemuscovite intergrowths within the zone of HAHA are either secondary, resulting from interaction of the granitic rock with a fluid phase, or represent remnant feldspars which were present within the leucomonzogranite prior to the high alumina metasomatism. The fact that andalusite appears to have crystallized within the cores of many plagioclase phenocrysts suggests the latter. Similar feldspar alteration has been widely accepted as being produced by intense hydrolysis attributed to interaction with a high temperature, sllica-rich, acldic fluid. Assuming A1 was inert, this process involved intense base leaching (remova1 of alkalis) with the crystallization of andalusite and perhaps even corundum at the approprlate temperature (Hemley et al., 1980; Beane, 1982).

The pristine nature of the albite and the common occurrence of an albite-andalusite assemblage indicates that albite was stable during andalusite formation ( $\left.\approx 600^{\circ} \mathrm{C} @ 2 \mathrm{~kb}\right)$ and perhaps may even have been a co-product of the reaction forming andalusite. These observations together with the relative absence of $\mathrm{K}$-feldspar implies that either the metasomatising fluid was Na-rich, or, converse1y, the physiochemical conditions attending the alteration event favoured the development of albite (e.g., high temperatures).

\section{Nature of the Hydrothermal System}

The replacement of oligoclase by aluminosilicates ( \pm spine1), requires a significant amount of $A 1$, and would release $\mathrm{S} 1, \mathrm{~K}, \mathrm{Na}$ and $\mathrm{Ca}$ to the fluid assuming a constant volume reaction (as suggested by unpub11shed data). Although the late appearance of apatite would account for redeposition of the $\mathrm{Ca}$, muscovite for $\mathrm{K}$, and albite for $\mathrm{Na}$, the fate of the silica is more problematic since the HAHA zone contains no free quartz. This differs from silica-rich, quartz-andalusite-pyrophyllitebearing high-alumina zones commonly described in the 11terature. The absence of a vuggy texture which characterizes desilicified granitic rocks (Cathelineau, 1986) indicates that quartz removal within the HAHA zone was not a later event and suggests that the desilicification process occurred either before or in conjuction with the high alumina metasomatism. The absence of any secondary quartz and the early presence of spinel suggests that the fluid involved in the HAHA process remained silica-undersaturated.

Whether alumina was a component of the fluid and therefore a moblle element has not been ascertained by this study. However, the presence of fluidderived alumina during development of the HAHA zone cannot be precluded. According to experimental studies by Anderson and Burnham (1983) to account for the appearance of feldspathold by the dissolution of feldspar at high temperatures, A1 can be transported in a fluid phase as an alkall complex. This process is temperature dependant (1.e., Al/Na ratio increases with temperature) and requires that the fluid be silica $\left(\mathrm{H}_{4} \mathrm{SiO}_{4}\right)$-poor and have a high $\mathrm{Na}-\mathrm{KC} 1 / \mathrm{HC} 1$ rat1o. Th1s Imp1les that $\mathrm{Al}$ complexing and transport is more significant where feldspars instead of micas are stable. These findings suggest that the ability of the silicapoor $( \pm \mathrm{Na}-\mathrm{rich})$ fluid (which attended the high alumina metasomatism) to transport A1 was perhaps substantial. The occurrence of andalusite assemblages instead of feldspathold indicates that a limited source of silica was avallable during metasomatism. However, the presence of spine1 indicates that domains of low silica concentration did exist during the early stages of the alteration. Alternatively, if albite was co-precipitated with andalusite then silica may have also been consummed according to the reaction: oligoclase + $\mathrm{Na}( \pm \mathrm{A} 1)$-fluid $\gg$ andalusite + albite + Ca.

The strong zonation of $\mathrm{Fe}$ within the andalusites marks a change in the iron species from ferric to ferrous. This, together with the low $\mathrm{Fe} /(\mathrm{Fe}+\mathrm{Mg})$ ratio of biotites in the HAHA zone, and the initial crystallization of hercynitic spinel, further implies that the fluid had a higher oxygen fugacity than that which affected the microgranite during earlier (auto?) metasomat1sm. Whether the increased oxygen fugacity is due to the presence of meteoric fluids or some other process (e.g., release of $\mathrm{H}_{2}$ gas, formation of $\mathrm{H}_{2} \mathrm{~S}$ ) remains unsolved and further studies will address this problem. Although the desilicifled nature of the HAHA zone is suggestive of meteoric waters (Hemley et al., 1980: Cathelineau, 1986), alternative processes are possible (e.g., quartz depletion in response albite formation). The presence of a $\mathrm{Na}( \pm \mathrm{A} 1)-\mathrm{rlch}$, silica-poor residual magmatic fluid suggests that the bulk composition of the me1t changed, a process perhaps related to the occurrence of earlier albitized and K-feldspathized rocks (C1arke and Muecke, 1985).

The chemistry of apatite indicates the existence 
Table 6. Representative microprobe analyses of feldspar from the HAHA zone. Structural formulae based on 320 .

\begin{tabular}{|c|c|c|c|c|c|c|c|c|}
\hline & 31 & 35 & 49 & 51 & 52 & 53 & 54 & 56 \\
\hline 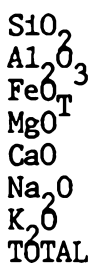 & $\begin{array}{r}67.99 \\
18.81 \\
0.05 \\
0.03 \\
0.06 \\
0.92 \\
10.09 \\
97.95\end{array}$ & $\begin{array}{r}64.39 \\
22.98 \\
0.01 \\
0.00 \\
2.94 \\
8.81 \\
0.28 \\
99.41\end{array}$ & $\begin{array}{r}64.67 \\
22.49 \\
0.03 \\
0.02 \\
2.51 \\
8.79 \\
0.29 \\
98.80\end{array}$ & $\begin{array}{r}63.76 \\
20.94 \\
0.04 \\
0.03 \\
3.02 \\
10.19 \\
0.26 \\
98.24\end{array}$ & $\begin{array}{r}67.46 \\
19.44 \\
0.11 \\
0.01 \\
0.46 \\
10.96 \\
0.16 \\
98.60\end{array}$ & $\begin{array}{r}65.05 \\
22.39 \\
0.13 \\
0.07 \\
2.32 \\
8.70 \\
0.46 \\
99.12\end{array}$ & $\begin{array}{r}64.27 \\
20.81 \\
0.13 \\
0.02 \\
2.71 \\
9.06 \\
0.32 \\
97.32\end{array}$ & $\begin{array}{r}62.87 \\
20.80 \\
0.00 \\
0.02 \\
1.88 \\
10.50 \\
0.22 \\
96.29\end{array}$ \\
\hline $\begin{array}{l}\mathrm{S} 1 \\
\mathrm{~A} 1 \\
\mathrm{Fe} \\
\mathrm{Mg} \\
\mathrm{Ca} \\
\mathrm{Na} \\
\mathrm{K}\end{array}$ & $\begin{array}{r}12.311 \\
4.014 \\
0.008 \\
0.008 \\
0.012 \\
0.323 \\
2.330\end{array}$ & $\begin{array}{r}11.366 \\
4.780 \\
0.001 \\
0.000 \\
0.556 \\
3.015 \\
0.063\end{array}$ & $\begin{array}{r}11.461 \\
4.697 \\
0.004 \\
0.005 \\
0.477 \\
3.020 \\
0.066\end{array}$ & $\begin{array}{r}11.469 \\
4.438 \\
0.006 \\
0.008 \\
0.582 \\
3.554 \\
0.060\end{array}$ & $\begin{array}{r}11.952 \\
4.058 \\
0.016 \\
0.003 \\
0.087 \\
3.765 \\
0.036\end{array}$ & $\begin{array}{r}11.493 \\
4.662 \\
0.019 \\
0.018 \\
0.493 \\
2.980 \\
0.104\end{array}$ & $\begin{array}{r}11.596 \\
4.424 \\
0.020 \\
0.005 \\
0.524 \\
3.169 \\
0.074\end{array}$ & $\begin{array}{r}11.504 \\
4.485 \\
0.000 \\
0.005 \\
0.369 \\
3.725 \\
0.051\end{array}$ \\
\hline $\begin{array}{l}\text { Or } \\
\mathrm{An} \\
\mathrm{Ab}\end{array}$ & $\begin{array}{r}87.44 \\
0.44 \\
12.12\end{array}$ & $\begin{array}{r}1.73 \\
15.30 \\
82.96\end{array}$ & $\begin{array}{r}1.84 \\
13.37 \\
84.78\end{array}$ & $\begin{array}{r}1.42 \\
13.87 \\
84.70\end{array}$ & $\begin{array}{r}0.93 \\
2.24 \\
96.82\end{array}$ & $\begin{array}{r}2.94 \\
12.46 \\
84.59\end{array}$ & $\begin{array}{r}1.95 \\
13.91 \\
84.13\end{array}$ & $\begin{array}{r}1.23 \\
8.89 \\
89.86\end{array}$ \\
\hline
\end{tabular}

inclusion in andalusite: 52

part of halo surrounding andalusite: $51,53,54,56$

hosts sillimanite: 35,49

replacement of albite: 31

Table 7. Representative microprobe analyses of apatite from the HAHA zone.

\begin{tabular}{lrrrrrrrr}
\hline & $1 \mathrm{R}$ & $1 \mathrm{C}$ & $2 \mathrm{R}$ & $2 \mathrm{C}$ & 3 & \multicolumn{1}{c}{4} & 5 & 6 \\
\hline $\mathrm{P}_{2} \mathrm{O}_{5}$ & 40.16 & 41.02 & 39.61 & 40.68 & 40.24 & 40.26 & 41.62 & 41.12 \\
$\mathrm{CaO}^{5}$ & 50.56 & 51.03 & 50.61 & 51.76 & 50.99 & 49.10 & 54.78 & 54.33 \\
$\mathrm{MnO}$ & 2.43 & 3.45 & 2.51 & 2.55 & 3.37 & 3.75 & 0.81 & 0.73 \\
$\mathrm{MgO}$ & 0.06 & 0.00 & 0.06 & 0.02 & 0.12 & 0.11 & 0.04 & 0.00 \\
$\mathrm{FeO}$ & 1.11 & 0.53 & 0.98 & 0.81 & 1.07 & 1.18 & 0.33 & 0.36 \\
$\mathrm{Y}_{2} \mathrm{O}_{3}$ & 0.14 & 0.26 & 0.10 & 0.07 & 0.00 & 0.08 & 0.20 & 0.31 \\
$\mathrm{SrO}$ & 0.03 & 0.01 & 0.00 & 0.02 & 0.00 & 0.00 & 0.00 & 0.04 \\
$\mathrm{~F}$ & 3.34 & 1.75 & 3.12 & 2.47 & 2.59 & 3.28 & 1.90 & 2.81 \\
$\mathrm{C} 1$ & 0.15 & 0.14 & 0.12 & 0.14 & 0.36 & 0.44 & 0.11 & 0.08 \\
$\mathrm{TOTAL}$ & 97.98 & 98.20 & 97.11 & 98.49 & 98.74 & 98.20 & 99.79 & 99.78 \\
\hline
\end{tabular}

1,2: $\operatorname{rim}(R)$ and $\operatorname{core}(C)$ sets from secondary apatites; HAHA zone

3,4: secondary apatites from altered leucomonzogranite (ph-1) 5,6: primary apatites as inclusions in biotite within granodiorite

of a volatile-( $F$ and $P$ ) and Mn-rich fluid phase during the late stages of hydrothermal activity. However, the presence of pyromorphite in fractures within the apatite and the subsequent overprinting of the HAHA zone by uranium-phosphate mineralization associated with intense hematization indicates that the waning stages of hydrothermal activity were also dominated by oxidizing fluids. The noted absence of garnets within the HAHA zone, although ubiquitous in the surrounding rocks, implies that the garnets were in disequilibrium with the fluid phase and may have possibiy contributed to the $\mathrm{Mn}$ rich nature of the fluid.

\section{CONCLUSIONS}

Phase assemblages and mineral chemistry suggest that the HAHA zone resulted by the interaction of a high temperature $\left(2620^{\circ} \mathrm{C}\right.$ a $\left.2 \mathrm{~kb}\right), \mathrm{Na}( \pm \mathrm{A} 1)-\mathrm{r} 1 \mathrm{ch}$, silica-undersaturated fluid with rock of 


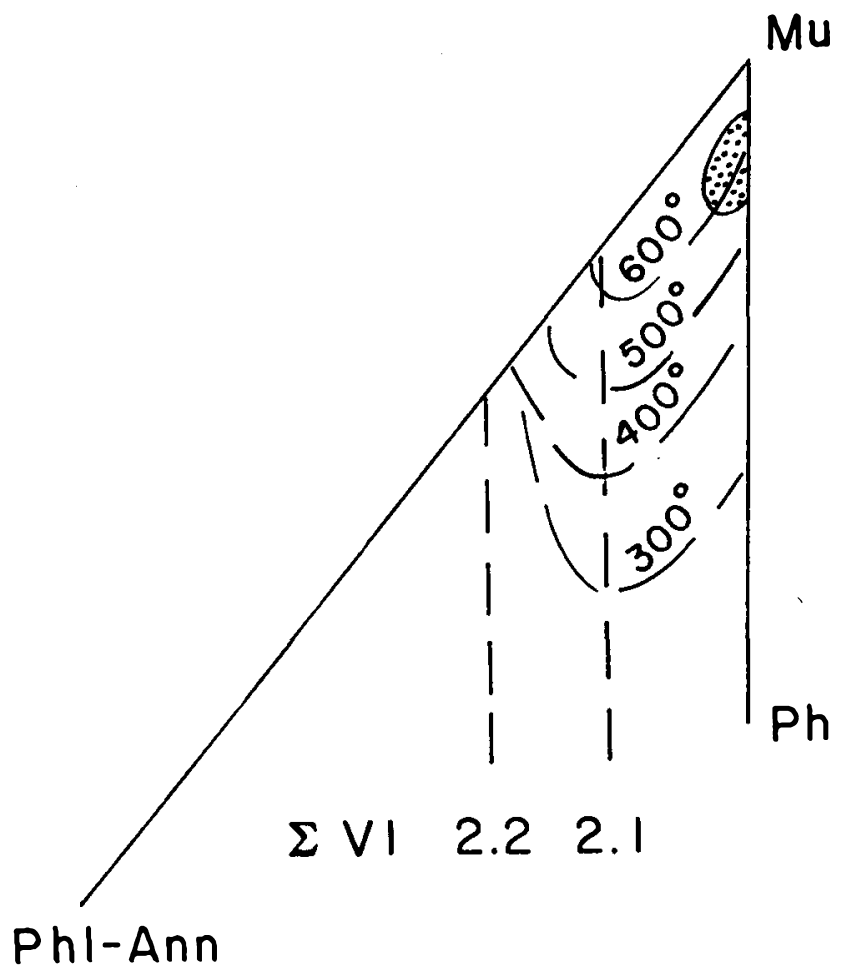

Fig. 9. Muscovites of the HAHA zone (shaded area) plotted on the $\sum \mathrm{v} 1$ versus $\mathrm{S} 1$ cation diagram of Monier and Robert (1986). Isotherms are shown by dashed (long) 11nes.

leucomonzogranite (unit 1) composition.

It is proposed that the fluid was of magmatichydrothermal origin, and that the fluid-reservoir was accessed by deep-seated faulting in response to increasing flutd pressure. The presence of numerous granodiortte xenoliths (roof pendants?) containing abundant Meguma Group metasedimentary xenoliths suggests that the evolution of the BIPI suite occurred at a relatively shallow level. The mineral chemistry of the various mineral phases within the HAHA zone and the nature of later superimposed alteration (hematitization) indicates that the magmatic-hydrothermal fluid possessed a high oxygen fugacity possibly reflecting interaction with meteoric fluids.

The occurrence of high alumina metasomatism within the SMB has implications beyond its association with a variety of mineral deposits. It represents but one of a serles of superimposed metasomatic events which affected the BIPI sulte and provides additional insight into interpreting the myriad of processes which operated within the SMB.

\section{ACKNOWLEDGEMENTS}

The author is greatly indebted to a number of people for their contributions. D.J. Kontak, G.A. O'Re111y, L.J. Ham, P.K. Smith, fellow SMEEBS and an anonymous reviewer are all extended thanks for their perceptive comments and constructive criticisms. J. Campbell and colleagues are acknowledged for their patience in providing quality 11lustrations. This work was funded and supported by the Nova Scotia Department of Mines and Energy through the Canada-Nova Scotia Mineral Development Agreement.

ANDERSON, G.M., and BURNHAM, C.W. 1983. Feldspar solub1lity and the transport of aluminum under metamorphic conditions. American Journal of Sclence, 283A, pp. 283-297.

BEANE, R.E. 1982. Hydrothermal aiteration in s1licate rocks. southwestern North America. In Advances in geology of the porphyry copper deposits, southwestern North America. Bdited by S.R. Titley. The University of Arizona Press, Tuscon. Ar1zona, pp. 117-137.

BOWMAN J.R. PARRY, W.T. KROPP, W.P. and KRUER, S.A. 1987. Chemical and 1sotopic evolution of hydrothermal solutions at Bingham, Utah. Economic Geology, 82, pp. 395-428.

BRIMHALL, G.H. JR. 1977. Early fracture-controlled disseminated mineralization at Butte, Montana. Economic Geology, 72, pp. 37-59.

CATHELINBAU, $M$. 1986. The hydrothermal alkal1 metasomat1sm effects on granitic rocks; quartz dissolution and related subsolldus changes. Journal of Petrology, 27, pp. 945-965.

CLARKE, D.B. 1981. The mineralogy of peraluminous granites: a review. Canadian Mineralog1st, 19, pp. 3-17.

CIARKB D.B. and MUBCKB G.K. 1985. Review of the petrochemistry and origin of the South Mountain Bathol1th and assoclated plutons, Nova Scotla, Canada. In H1gh Heat Production (HHP) Granttes. Hydrothermal Circulation and Ore Genes1s. Inst1tute of Mining and Metallurgy, London, England, pp. 41-54.

CLARKB, D.B., MUBCKB, G.K., and CHATTERJEB, A.K. 1985. The South Mountain Batholith: Geology, petrology, geochemistry. In Guide to the Granttes and Mineral Deposits of Southwestern Nova Scotia. Edited by A.K. Chatterjee and D.B. Clarke. Nova Scot1a Department of Mines and Energy. Paper 85-3, pp. 1-15

CLARKB, D.B., MCKEENZIB, C.B. , MUECKB, G.K., and RICHARDSON, S.W. 1976. Magmat1c andalusite from the South Mounta1n Batholith. Nova Scotia. Contributions to Mineralogy and Petrology, 56, pp. 279-287.

COREY M.C. 1986. Bedrock geology of the South Mountain Bathol1th; NTS map sheet $11 \mathrm{D} / 13$. In Mines and Minerals Branch, Report of Activities, 1985. Bdited by J.L. Bates. Nova Scotia Department of Mines and Energy. Report 86-1. pp. 137-148.

DILLES, J.H. 1987. Petrology of the Yerington Bathollth, Nevada; evidence for evolution of porphyry copper ore fluids. Economic Geology, 82, pp. 1750-1787.

FARLEY, E.J. 1978. Mineralization of the Turner and Walker deposits of the South Mountain Bathol1th. Unpublished M.Sc. thesis, Dalhousie University, Halifax, Nova Scotia.

GRAMBLING J.A. and WILLIAMS, M.L. 1985. The effects of $\mathrm{Fe}^{3+}$ and $\mathrm{Mn}^{3+}$ on aluminum s1l1clate phase relationships in north central New Mexico, USA. Journal of Petrology, 26, pp. 324354.

GUSTAFSON, L.B., and HUNT, J.P. 1975. The porphyry copper deposit at E1 Salvador. Chile. Economic Geology, 70, pp. 857912.

HAM, L.J., and HORNB, R.J. 1986. Geology of the South Mounta1n Bathol1th on the eastern half of NTS map sheet 21A/16. In Mines and Minerals Branch Report of Act1vities, 1985. Edited by J.L. Bates. Nova Scotia Department of Mines and Energy. Report 86-1, pp. 149-159.

HELGESON, H.C. 1985. Some thermodynamic aspects of geochemistry. Pure and App11ed Chemistry. 57, pp. 31-44.

HEMLEY, J.J. , MONTOYA, J.W. , MARINENKO, J.W. , and LUCE. R.W. 1980. Equilibria in the system $\mathrm{Al}_{2} \mathrm{O}_{3}-\mathrm{S}_{10} \mathrm{H}_{2} \mathrm{O}$ and some general implications for alteration/minerál1zatioh processes. Economic Geology. 75. pp. 210-228.

JACOBS, D.C. . and PARRY, W.T. 1979. Geochemistry of blotite in the Santa R1ta porphyry copper deposit, New Mexico. Economic Geology. 74, Pp. 860-887.

JAMIESON, R.A. 1974. The Contact of the South Mountain Batholith near Mount Uniacke. Nova Scotia. Unpublished B.Sc. thes1s, Dalhousie University, Hallfax, Nova Scotla.

KONTAK, D.J., and COREY, M.C. In press. Metasomatic origin for spessartine-rich garnets in the South Mounta1n Batholith, Nova Scotia. Canadian Mineralogist, 26.

LEBEL, L. 1979. M1cas magmatiques et hydrothermaux dans 1 'environnement du porphyre cuprifere de Cerro Verde-Santa Rosa, Perou. Bulletin de Mineralogy, 102, pp. 35-41.

LEMIERE, B.. DELFOUR, J. , MOINE, B. , PIBOULE, M. , PLOQUIN, A. ISNARD, P. , and TBGYEY, M. 1986. Hydrothermal alteration and the formation of aluminous haloes around sulfide deposits. Mineralium Deposita, 21, pp. 147-155

MACDONALD, M.A., and CLARKE, D.B. 1985. The petrology, geochemistry, and economic potentlal of the Musquodobo1t Batho11th, Nova Scot1a. Canadian Journal of Barth Sclences 22. Pp. 1633-1642. 
MCKENZIB, C.B. 1986. Geology and mineralization of the Chetwynd deposit, Southwestern Newfoundland, Canada. In Proceedings of Gold ' 86 , An International Symposium on the Geology of Gold. Edited by A.J. MacDonald. Toronto, 1986. pp. $137-148$.

MCKKNZIE, C.B. , and CLARKE, D.B. 1975. Petrology of the South Mountain Bathol1th, Nova Scotia. Canadian Journal of Earth Sclences, 12, pp. 1209-1218.

MILLER, C.F. STODDARD, E.F., BRADFISH, L.J. . and DOLLASE, W.A. 1981. Composition of plutonic muscovite: genet1c 1mplications. Canadian Mineralog1st, 19. pp. 25-34.

MONIER, G., and ROBERT, J.L. 1986. Muscovite sol1d solutions in the system $\mathrm{K}_{2} \mathrm{O}-\mathrm{MgO}-\mathrm{FeO}-\mathrm{Al}_{2} \mathrm{O}_{3}-\mathrm{S}_{10}-\mathrm{H}_{2} \mathrm{O}$ : an experimental study at 2 kbar $\mathrm{PH}_{2}^{2} \mathrm{O}$ and comparison with hatural L1-free white micas. Mineralogical Magazine, 50, pp. 257-266.

NILSSON, C.A. 1968. Wall rock alteration at the Bollden deposit, Sweden. Economic Geology, 63, pp. 472-494.

PANTELEYBV A. 1986. Canadian Cord1lleran model for ep1thermal gold-s11ver deposits. Geoscience Canada, 13, pp. 101-111.

POLLARD, P.J. . and TAYLOR R.G. 1986. Progressive evolution of alteration and tin mineralization; controls by intersititial permeablitty and fracture-related tapping of magmatic fluid reservoirs in tin granites. Economic Geology, 81, pp. 17951800 .

ROBIE, R.A., and HEMINGWAY, B.S. 1984. Entropics of kyantte andalusite, and sillimanite: additional constraints on the pressure and temperature of the $\mathrm{Al}_{2} \mathrm{~S}_{10}$ triple point. American Mineralog1st, 69, pp. 298-306.

SCHMIDT, R.G. 1985. High alumina hydrothermal systems in volcanic rocks and their significance to mineral prospecting in the Carolina Slate Belt. United States Geological Society Survey Bulletin 1562.

Survey Bulletin 1562.
STEEFEL, C.I. and ATKINSON, W.W., JR. 1984. Hydrothermal andalusite and corundum in the E1khorn District. Montana. Economic Geology, 79, pp. 573-579.

STRONG, D.F. and CHATTERJEE, A.K. 1985. A review of some chemical and mineralogical characteristics of granituld rocks hosting $\mathrm{Sn}$. W, U. Mo deposits in Newfoundland and Nova Scotia. In High Heat Production (HHP) Granites, Hydrothermal Circulation and Ore Genesis. Institute of Mining and Metallurgy, London, England, pp. 489-516.

SPRY, P.G. 1987. Compositional zoning in zincian spinel. Canadian M1neralog1st. 25. pp. 97-104. 